\title{
ORGANIZATION OF CZECH AND POLISH ADMINISTRATIVE JUDICIARY
}

\section{David Kryska*}

\section{Faculty of Law, Charles University in Prague, Czech Republic email: David.Kryska@seznam.cz}

KRYSKA, David. Organization of Czech and Polish Administrative Judiciary. International and Comparative Law Review, 2012, Vol. 12., No. 1, pp. 81-102. DOI: 10.1515/iclr-2016-0080.

\begin{abstract}
The author, on the occasion of the tenth anniversary of most recent reforms of administrative judiciary in the Czech Republic and the Republic of Poland, compares the legislation of Czech and Polish administrative judiciary. The article is divided into three parts, the first two discuss the legislation in both countries. Constitutional foundations of the organization and the system of administrative judiciary are addressed there. Subsequently, the author deals separately with the legislation of lower levels of the system and the legislation of supreme administrative courts, focussing on judges and other professional staff and the structure of the courts. Both the parts are rounded by an interpretation of the instruments for unification of the judicature. The third part of the paper includes the final summary.
\end{abstract}

Keywords: The Czech Republic, Poland, Organization of Administrative Judiciary

\section{Introduction}

About ten years ago, acts were adopted in the Czech Republic and Poland which in both countries finalized the reform process in administrative judiciary. A problematic point of the reforms was the question of organising the reformed administrative judiciary. It appears to be appropriate to compare amendments of the organization of administrative judiciary in countries in which the intellectual and historical foundations of judicial control of public administration are often different, but in fact very similar, almost identical. ${ }^{1}$

\footnotetext{
* Mgr. David Kryska. Internal Ph.D. student, Department of Administrative Law and Administrative Science, Faculty of Law, Charles University in Prague. My true appreciation goes to Mgr. Eliška Vránová, M.A. for her great involvement in translation of this article. Email: David.Kryska@seznam.cz

1 See MIKULE, Vladimír. Czeskie i polskie sądownictwo administracyjne - czy tradycyjna zgodność, czy też wystąpią różnice? In: Instytucje wspótczesnego prawa administracyjnego. Ksiega jubileuszowa Profesora zw. dra hab. Józefa Filipka. Cracow: Wydawnictwo Uniwersytetu Jagiellońskiego, 2001, p. 479-487.
} 


\section{Czech Republic}

\subsection{Foundations of the organization of administrative judiciary}

Constitutional basis for the organization of the Czech administrative judiciary is laid out by Article 91 of the Constitution of the Czech Republic and by Article 92 of the Constitution of the Czech Republic. ${ }^{2}$ According to these provisions, the court system consists of the Supreme Court, the Supreme Administrative Court, high courts, regional and district courts. The Supreme Court is the supreme judicial authority in matters falling within the jurisdiction of courts except for the matters decided by the Constitutional Court and the Supreme Administrative Court. At the same time, the constitutional order of the Czech Republic does not stipulate a clear organizational model of administrative judiciary. The Supreme Administrative Court represents the ultimate judicial authority for administrative judiciary matters, however, ${ }^{3}$ it may be seen as the supreme element in the administrative judiciary system, or as the only element, as well as being a mere "diversion" from the system of other courts in administrative judiciary matters. ${ }^{4}$

These foundations also served as bases for theses in the preparation of the current arrangements in administrative judiciary. ${ }^{5}$ Three options of organizational arrangement of administrative judicial system were considered: 1) general courts and the Supreme Court, 2) general courts and the Supreme Administrative Court and 3) system of administrative courts lead by the Supreme Administrative Court. Since the first option would require a constitutional change in the sense that the Supreme Administrative Court would have to be excluded from the court system, and the third option would require the establishment of new special administrative courts which would, together with the Supreme Administrative Court, constitute the whole system of administrative judiciary, the compromise second option was chosen. This option was considered in the government's proposal of the code of administrative judiciary, ${ }^{6}$ which was approved as the code of administrative judiciary (hereinafter referred to as c.a.j.). ${ }^{7}$ Administrative judiciary in the Czech Republic is administered on lower levels by general courts and on a higher level by the Supreme Administrative Court as a special court (organic administrative judiciary).

2 Constitutional Act No. 1/1993 Coll.

3 See SLÁDEČEK, Vladimír, MIKULE, Vladimír, SYLLOVÁ, Jindřiška. Ústava České republiky. Komentár. Prague: C.H.Beck, 2007, p. 760.

4 MAZANEC, Michal. Správní soudnictví. Prague: Linde Praha, 1996, p. 44.

5 See Výchozí teze pro př́pravu koncepce správního soudnictví a možné varianty jeho organizační struktury. Právní praxe, 2000, No. 6.

6 Parliament of the Czech Republic, the House of Deputies, 2001 , III. election period, the House print No. 1080.

7 See Act No. 150/2002 Coll. 
In the Czech Republic, organizational standards regulating the basic status of courts in the administrative judiciary and their judges are included in the code of administrative judiciary, which does not constitute a regulation of purely procedural nature. As indicated above, in the Czech Republic the court system is represented by district courts, regional courts, high courts, the Supreme Court and Supreme Administrative Court. In the Czech administrative judiciary, however, only regional courts and the Supreme Administrative Court act and make decisions. ${ }^{8}$ However, unless otherwise provided by the code of administrative judiciary, general legal provisions apply to the organization of courts and the status of judges deciding in administrative judiciary, ${ }^{9}$ particularly the act on courts and judges. ${ }^{10}$

In accordance with the Constitution of the Czech Republic, courts are independent authorities exercising judicial power in the name of the republic. Judges are appointed for no fixed term, they are independent in the performance of their duties and their impartiality must not be endangered. ${ }^{11}$

\subsection{Regional courts as administrative courts}

Czech Republic has a total of 8 regional courts. Circuits of regional courts are laid out according to the circuits of district courts. ${ }^{12}$ This is based on the territory of regions in accordance with the territorial subdivisions of the state, ${ }^{13}$ not regions as higher territorial administrative units. ${ }^{14}$ The act has also established 7 branches of regional courts which do not constitute independent courts of law ${ }^{15}$ but represent organizational components of individual regional courts. ${ }^{16}$ In each residential town in a region, seen as a higher territorial administrative unit, there is either a regional court, or its branch. Whether or not a certain branch of a regional court also discusses and decides administrative judiciary matters is determined by the presiding judge of the regional court in work contour. ${ }^{17}$

Regional court is composed of the presiding judge, vice-presidents, presiding judges of benches and other judges. ${ }^{18}$ Administrative judiciary matters are decid-

$8 \quad$ See $\$ 3(1)$ c.a.j.

9 See $\$ 3$ (2) c.a.j. The organization of administrative courts is regulated by $\$ 11-31$ in c.a.j.; provisions on the status of judges in the administrative judiciary are regulated in $₫ 121$ 124.

10 Act No. 6/2002 Coll.

11 See art. 81, 82 and 93 of the Constitution of the Czech Republic.

12 See Annex No. 2 of the act on courts and judges.

13 See Act No. 36/1960 Coll.

14 See Constitutional Act No. 347/1997 Coll. In accordance with this constitutional law, there are 14 higher territorial administrative units in the Czech Republic.

15 See Annex No. 5 and 6 of the act on courts and judges.

16 See e.g. KOCOUREK, Jiří, ZÁRUBA, Jan. Zákon o soudech a soudcích. Zákon o státním zastupitelství. Prague: C.H.Beck, 2004, p. 176.

17 See $\$ 41$ (2) in conjunction with $₫ 42$ (1) letter b) of the act on courts and judges.

18 See $\$ 30(1)$ of the act on courts and judges. 
ed by specialised benches consisting of a chair and two judges. Cases defined by law are decided by specialised single judge. The basis for internal organization of regional courts are judicial departments based on benches and single judges. ${ }^{19} \mathrm{At}$ the first level, administrative judiciary is carried out by general courts; however, it is functionally separated in their internal organization. ${ }^{20}$ The law therefore provides for specific functional jurisdiction for decision-making in the administrative judiciary matters by regional courts.

Judges of regional courts are, in accordance with the Constitution of the Czech Republic, appointed by the President with countersigning of the Prime Minister or a member of the government authorised by the Prime Minister. ${ }^{21} \mathrm{~A}$ citizen of the Czech Republic can be appointed a judge, if they have legal capacity and integrity, if their experience and moral qualities guarantee that they will hold their office properly, they have reached at least the age of 30 on the day of being appointed and agree to their being appointed as a judge and being allocated to a specific court. A prerequisite for being appointed as a judge is university education obtained by proper graduation from a Master's study program in law at a university in the Czech Republic and passing a professional judicial examination. The following examinations are also considered as a professional judicial examination: bar examination, law candidate's final examination, notary examination and professional bailiff examination. The same effects are obtained by performing the duties of the Constitutional Court judge for the period of at least 2 years. ${ }^{22}$

Administrative court judges are subject to special requirements. A judge can be appointed, subject to their consent, to decide in administrative matters at regional courts if they have performed legal, scientific or teaching practice in constitutional, administrative or financial law for at least 5 years, or, if their appointment can be justified by the results of their preparatory service and judicial examination. The Minister of Justice allocates the judge to a specific court after their appointment and making the oath. ${ }^{23}$ Temporary allocation is also possible. ${ }^{24}$ In this case, the Minister of Justice shall make the decision, following a proposal by the presiding judge of the particular regional court to which the judge is to be temporarily assigned, after discussion with presiding judge of the court where the judge performs their duties. ${ }^{25}$ At the same time, a judge allocated to a certain court may be, with their consent or upon their request, transferred to perform their duties at another court. The transfer will be decided

19 See $\$ 40$ (1) of the act on courts and judges.

20 VOPÁLKA, Vladimír et al. Soudní rád správní. Komentárir. Prague: C.H.Beck, 2004, p. 8.

21 See art. 63 (1) letter i) and (3) of the Constitution of the Czech Republic.

22 For prerequisites for the office of a judge see $\$ 60$ act on courts and judges.

23 See $\$ 67$ act on courts and judges.

24 VOPÁLKA, Vladimír et al., op. cit., p. 294.

25 See $\$ 68(2)$ letter $c$ ) of the act on courts and judges. 
by the Minister of Justice after consulting with the presiding judge of the court to which the judge is to be transferred. ${ }^{26}$

Separate issue in the legal status of judges of courts in administrative judiciary is ensuring their adequate expertise or specialisation in the field of administrative law. On one hand, the law stipulates higher requirements on judges at administrative courts, at the same time theses in the preparation of the current arrangements of administrative judiciary expected a broader involvement of specialists in administrative law from scientific institutions, law faculties and administrative authorities. Three options were discussed: a) appointing these persons as administrative court judges, $b$ ) employing them as assistant judges or c) employing them as special lay jurors. ${ }^{27}$ The act, however, does not count on too much "permeability" of such experts into the functions of judges or assistant judges. Administrative judiciary then doesn't count at all with the institute of lay jurors.

The decision-making activities of regional courts involve, in addition to judges, also higher court officers, judicial associates and judicial secretaries, as well as assistant judges, ${ }^{28}$ to the extent provided for by the act on higher court officers, ${ }^{29}$ or by the rules of procedure for district and regional courts. ${ }^{30}$

Higher court officers ${ }^{31}$ and judicial secretaries ${ }^{32}$ are court staff who may carry out certain acts of the court. Regional court judges may appoint assistant judges ${ }^{33}$ Assistant judge is appointed by the president of a regional court following a proposal by the judge, whose assistant is to be appointed, and is dismissed even without proposal. The assistant judge function is considered to be repealed, shall the function of the particular judge cease. They are entitled to participate in decision-making activities of the court in the scope specified for higher court officers and also provisions governing the status of higher court officers shall be adequately applied. Judicial associate is a person in the preparatory service for judicial associates, the purpose of which is to professionally prepare judicial associates for performing the duties of a judge. Judicial associate is entitled to

26 See $\$ 71(1)$ and $₫ 73(1)$ of the act on courts and judges.

27 See Výchozí teze pro přípravu koncepce správního soudnictví a možné varianty jeho organizační struktury. Právní praxe, 2000, No. 6, p. 363.

28 See $\$ 30$ (3) in conjunction with $₫ 36$ a (5) of act on courts and judges.

29 See $\$ 10(3)$ and $\$ 11-14$ Act No. 121/2008 Coll., on higher court officers and senior officials of the state prosecution and on the related laws, as amended (hereinafter referred to as the act on $\mathrm{HCO})$.

30 See $\$ 6$ (3) of the Ministry of Justice decree No. 37/1992 Coll. , on rules of procedure for district and regional courts, as amended.

31 See $\$ 2(1)$ and (3) of HCO.

32 In accordance with $₫ 27$ of act of the judicial HCO judicial secretaries may, until 31 December 2013, carry out the operations of the court, which, according to the law may be carried out by higher court officers, to the extent and under the conditions laid down by the decree on the rules of procedure for district and regional courts.

33 See $\$ 36 \mathrm{a}$ act on courts and judges. 
carry out court operations under the conditions and to the extent stipulated by specific legal regulation. ${ }^{34}$

President and Vice-Presidents of regional court are court officials and in addition to the decision-making activities they also perform the administration of the regional court. ${ }^{35}$ President of the regional court shall be appointed by the President of the Republic from among judges, following a proposal from the Minister of Justice. Vice-Presidents of regional courts are appointed by the Minister of Justice from among judges, following a proposal by the President of a regional court. ${ }^{36}$ The term of office of the President and Vice-President of regional court is 7 years. President or Vice-President of regional court may be removed only by the decision of a disciplinary court in disciplinary proceedings. Functions of the President and Vice-President of the court also cease as a result of termination of office of the judge, resignation or expiration of the term. President of regional court initiates - based on final decision of the regional court in administrative judiciary - the adoption of opinion by the Supreme Administrative Court. If requested by the Supreme Administrative Court, the President of the regional court submits a statement prior to the adoption of the opinion. ${ }^{37}$ Presiding judges of benches in addition to decision-making activities also organise and govern the activities of the benches. ${ }^{38}$

In addition to the President and Vice-Presidents of the regional court, or, where appropriate, presiding judges of benches, other judges and staff operating in the court, the authority for administration of justice (in this case the central one) is the Ministry of Justice. ${ }^{39}$ It performs the administration of regional courts either directly or through the Presidents of the courts. ${ }^{40}$ The Ministry of Justice issues the already quoted rules of procedure for regional courts in the form of regulations, and in the form of internal regulation it issues internal and office rules of procedure. ${ }^{41}$

A five-member Judicial Council also operates at regional courts as an advisory body for the President of the court. ${ }^{42}$ The function of the Judicial Council member is incompatible with that of the President and Vice-President of the court. The Judicial Council of a regional court expresses its opinion in particu-

34 For more detail see. $\$ 109-113$ act on courts and judges.

35 See $\$ 30(2)$ and $\$ 104, \S 106$ and $\S 108$ of the act on courts and judges.

36 In each regional court the section of administrative judiciary falls under the scope of one of the Vice-Presidents.

37 See $\$ 32$ act on courts and judges.

38 See $\$ 30(2)$ of the act on courts and judges.

39 See $\$ 119$ and 120 of the act on courts and judges.

40 For more on state administration of regional courts see in particular $\$ 123$ and $\$ 126$ act on courts and judges.

41 Instructions of the Ministry of Justice No. 505/2001 - Org., by which the internal and office rules of procedure are issued for district, regional and high courts, as amended.

42 See $\$ 46-59$ act on courts and judges. 
lar on the candidates to be appointed the President and Vice-President of the regional court, on the judges who are to be assigned or seconded to exercise the function in the regional court or who are to be transferred from the regional court to another court, or on the judges who are to be appointed the presiding judge of bench at regional court, and, in relation to fundamental issues of state administration, it also examines the proposed work contour of the regional court and its amendments. Members of Judicial Council and their 3 alternate members are elected by the assembly of all judges who were assigned or seconded to exercise their function to the competent court, from among these judges. The term of office in the Judicial Council is 5 years.

\subsection{Supreme Administrative Court}

It took ten years of efficiency of the Czech Constitution before the Supreme Administrative Court (further referred to as SAC) was established in accordance with the Constitution's above cited provisions. ${ }^{43}$ In accordance with the mentioned constitutional definition, the SAC is marked by judicial regulations as the "ultimate judicial authority in matters falling in the powers of the courts in the administrative judiciary ensuring the unity and the legality of their decisions", ${ }^{4}$ which shall act as the authority of the first and only instance in the administrative judiciary, as well as the authority of the second instance in the framework of the decision-making about cassation appeals. The Supreme Administrative Court is located in Brno.

The Supreme Administrative Court consists of the President of the court, Vice-President of the court, heads of court divisions, presiding judges of benches and other judges.

Decision-making of the Supreme Administrative Court is performed by judges. With regard to lawful requirements for SAC judges, it can be noted that a judge can be, with prior consent of the President of the SAC and the judge himself, allocated to the SAC, if for the period of at least 10 years they pursued a legal practice or scientific or teaching activities in the field of constitutional, administrative or financial law. The judge may be transferred to the SAC with their consent or at their request, if they have had a legal practice for at least ten years, and their professional knowledge and experience gives guarantee for proper exercise of this function. The law in this case lowers the additional requirements regarding judges in administrative courts in relation to their knowledge of constitutional, administrative and financial law. On the other hand, it requires that the candidates' professional knowledge and experience guarantee proper discharge of this function. The judge can be transferred to discharge function at the SAC only with the consent of the President of the court.

43 See $\$ 11$ c.a.j.

44 See $\$ 12(1)$ c.a.j.

(C) Palacký University Olomouc, Czech Republic, 2012.

ISSN 1213-8770 (print), ISSN: 2464-6601 (online). 
Each judge of the SAC appoints at least one assistant judge, who is appointed and recalled by the President of the SAC following a proposal from the judge, whose assistant this is. The assistant judge function is considered to be repealed, shall the function of the particular judge cease. A citizen showing integrity can be appointed as assistant judge, who has a Master's degree in law from a university in the Czech Republic. Assistant judge performs individual acts of the administrative court proceedings on behalf of a SAC judge. ${ }^{45}$

President and Vice-President of the SAC are appointed from among the judges of the court the President of the Republic. ${ }^{46}$ Their recalling is regulated by the above mentioned adjustment in the act on courts and judges. The term of office of the President and Vice-President of the SAC is 10 years. The President and Vice-President of the SAC may be appointed repeatedly, if, during the time of their office they were not found responsible for any disciplinary offense committed in the course of this function, or if they were not sentenced for a criminal offense during the period of their function.

President and Vice-President of the SAC perform, in addition to the decisionmaking activities, also the administration of the court. The President of the SAC appoints heads of court divisions and presiding judges of benches from among the judges of the court. ${ }^{47}$ The President of the SAC issues, following a discussion in plenary, the rules of procedure of the Supreme Administrative Court. ${ }^{48}$

SAC judges are classified by the schedule of work into court divisions according to the main focus of their activities. The SAC plenary decides on the number of court divisions, following a proposal by the President of the SAC. Two divisions have been set up by the plenary: financial-administrative division and social-administrative division. ${ }^{49}$ Activities of the court divisions are organised and governed, in addition to decision-making activities, by the heads of court divisions.

45 See also $\$ 29$ a Rules of Procedure of the SAC.

46 For powers of the President of the SAC see also $\$ 3$ of the Rules of Procedure of the SAC.

47 See $\$ 102(4)$ of the act on courts and judges.

48 The rules of procedure of the SAC, as well as the organizational regulations, are available on the Supreme Administrative Court's website at www.nssoud.cz

49 Within the scope of the financial-administrative division falls decision-making in matters of taxes, charges, duties, accounting, protection foreign investments, prices, securities, collective investments, pension funds and pension supplementary insurance, insurance, protection of competition and public procurement, hallmarks, lotteries, and other similar games; in the scope of the social-administrative division then falls pension insurance, oneoff financial compensation, sickness insurance, insurance premiums on the social security and contribution to the state employment policy, health insurance, health and safety, social assistance, state social support, social and legal protection of children, employment and safety at work, interest and professional self-government, business relationships (cf. Plenary resolution of the SAC from 29 April 2004, as amended by Plenary resolution of the SAC of 20 December 2006, www.nssoud.cz). 
All the judges of the SAC form the plenary of the SAC. Plenary meetings are not open for the public, but the Minister of Justice and the President of the Supreme Court have the right to participate. Other persons can also be invited to the plenary meetings. The plenary gives opinions on the decision-making activities of courts in certain matters, decides on which decision of the court and regional courts will be published in the Collection of Decisions, it examines the rules of procedure and its amendments, following a proposal by the President of the court it decides on the number of court divisions, their establishment, fusions and content of their activities. ${ }^{50}$

The Supreme Administrative Court issues the Collection of Decisions of the Supreme Administrative Court, in which in particular selected decision of the SAC and regional courts issued in the administrative judiciary are published, and also the opinions and a major resolutions of the Supreme Administrative Court.

The SAC also houses five-member Judiciary Council of the SAC. The function of a member of the Judicial Council is incompatible with that of the President, Vice-President and head of court division of the Supreme Administrative Court. Judicial Council is the advisory body of the President of the SAC. Judicial Council, inter alia, expresses its opinion on candidates for the head of a court division and the presiding judge of a bench of the Supreme Administrative Court, on judges who are to be assigned and transferred to serve at the Supreme Administrative Court or who are to be transferred from the Supreme Administrative Court to another court, discusses proposals for the work schedule of the Supreme Administrative Court and its changes, expresses its opinion on key issues of the state administration of the SAC. This is decided on the proposal of the President of the SAC, if the Judicial Council does not respond within the time limit, it is understood to approve the suggestion. Judicial Council may also ask the President of the Supreme Administrative Court to convene the Plenum and suggest the agenda of the session to him.

In addition to the President and Vice-President of the SAC, the Ministry of Justice also carries out the state administration of the SAC through the President of the SAC. ${ }^{51}$ The director of the administration of the SAC is also involved.

Office of the President of the Court and the Department of Documentation and Analysis also operate within the SAC. ${ }^{52}$

The Supreme Administrative Court acts also as the "disciplinary court" in matters of judges and judicial officials, even the judges in the administrative judiciary. $^{53}$

50 See $\$ 11$ of the Rules of Procedure of the SAC.

51 On the scope of state administration of the SAC see $\$ 28-29$ c.a.j.

52 See $₫ 8$ and $₫ 31$ to 37 and $₫ 11$ and $\$ 12$ of the organizational order of the SAC.

53 See Act No. 7/2002 Coll., on the management in the matters of judges, state prosecutors 


\subsection{The Supreme Administrative Court as the highest body of the admini- strative judiciary}

As indicated above, the Supreme Administrative Court is the highest judicial authority in matters falling in the powers of courts in the administrative judiciary, ensuring unity and legality of their decision-making. It has been equipped with certain powers and institutes to perform these tasks.

In the first place, SAC decides in cases defined by the law about cassation appeals, representing an extraordinary appeal against final decisions of regional courts. ${ }^{54}$ Decision-making on cassation appeals unifies the judicature of regional courts. ${ }^{55}$

In contrast, unification of decision-making activities of the SAC itself is regulated by submitting matters to enlarged benches of judges. ${ }^{56}$ If a bench of the Supreme Administrative Court has in its decision arrived at a legal opinion which differs from the legal opinion already expressed in the previous decision made by the Supreme Administrative Court, the bench shall refer the matter to an extended bench for its decision. On referring the matter, the bench shall provide reasons for its legal opinion. An extended bench of judges consists of a presiding judge and six judges in case the bench consist of a presiding judge and two judges, and it consists of a presiding judge and eight judges in case the bench consists of a presiding judge and six judges. By referring the matter to the extended bench, the power of making the decision is transferred as well. If the extended bench agrees with the different opinion, it shall discuss the matter and decide; in case that the bench does not agree, the matter comes back for consideration and decision to the bench by the extended bench's ruling. ${ }^{57}$ The procedure of the submission of matters to the enlarged bench shall not apply in case that the different legal opinion has already been noted in the SAC's opinion.

Another such instrument is represented by the just mentioned opinion of the SAC. ${ }^{58}$ Supreme Administrative Court shall follow and assess final decisions of courts of administrative judiciary and, on the basis of these decisions in the interest of unite judicial decision-making, shall adopt a position on judicial

and bailiffs, as amended.

54 See $\$ 12(1)$ and $\$ 102$ an. c.a.j.

55 To the Czech cassation appeal see e.g. SLÁDEČEK, Vladimír, TOMOSZKOVÁ, Veronika et al. Správní soudnictví v České republice a ve vybraných státech Evropy. Prague: Wolters Kluwer, 2010, p. 69-72 and literature referred to therein. Some of its aspects were discussed in the Czech-Polish comparative view in my paper KRYSKA, David. K reformatorní pravomoci českého a polského Nejvyššího správního soudu v řízení o kasační stížnosti. In ŠTURMA, Pavel (ed.) 1. celostátní studentská vědecká konference SVOČ v oboru právo a právní věda. Prague: Charles University, Faculty of Law published by Eva Rozkotová, 2011, p. 83-101.

56 See $\$ 16(3)$ and $\$ 17$ c.a.j.

57 See VOPÁLKA, Vladimír et al., op. cit., p. 28-30.

58 See $\$ 12(2)$ and $\$ 19$ c.a.j. 
decision-making in specific matters. Delivering an opinion can be suggested by the President of the Supreme Administrative Court, head of court division or the extended bench. The opinion shall be adopted by the CAS in the court division but in cases relating to more court divisions or disputed between them, the President of the CAS may propose that the Plenary form an opinion. Before forming an opinion, the Supreme Administrative Court may request an opinion from administrative authorities and other authorities, administrative benches of regional courts and other persons.

In its decision-making, the Supreme Administrative Court may - in the interests of lawful and uniform decision-making by administrative authorities - make a ruling of an exemplary nature. ${ }^{59}$ If the bench of the CAS in its decision-making forms repeatedly legal opinion different from the legal opinion on the same legal question, on which a decision by an administrative authority is based, it may submit the legal question for consideration to the enlarged bench composed of the President and eight judges. If the extended bench forms legal opinion identical with the current decision-making activities of the Supreme Administrative Court, it shall make it a ruling of an exemplary nature. Rulings of an exemplary nature are published in the Collection of Decisions of the SAC and are sent to the authority concerned by the said decision, and the competent central administrative authority (signalling power).

The president of the SAC may also submit other legal questions to the extended bench for their consideration. ${ }^{60}$

\section{Poland}

\subsection{Foundations of the organization of administrative judiciary}

As opposed to the situation in the Czech Republic, the Polish constitutioner assumed a creation of a whole network of special administrative courts in the technical sense (organic administrative judiciary), completely separate from other courts. By administrative courts I mean, in accordance with Article 184 of the Constitution of RP, ${ }^{61}$ Supreme Administrative Court and other administrative courts. System of administrative courts must therefore consist of at least two levels, which corresponds also with the constitutional principle of two-instance proceedings $^{62}$ requiring the legal proceedings (i.e. also in the administrative judiciary) to be at least two-instance (but it may also be three-instance). ${ }^{63}$

59 See $\$ 12(3)$ and $\$ 18$ c.a.j.

60 See $\$ 18(4)$ c.a.j.

61 Constitution of the Republic of Poland of 2 April 1997 (Coll. 1997 No. 78, item 483).

62 See art. 78 and art. 176 (1) of the Constitution of PR.

63 See WINCZOREK, Piotr. Komentarz do Konstytucji Rzeczypospolitej Polskiej z dnia 2 kwietnia $1997 r$. Warsaw: Liber, 2000, p. 230-231. 
Adoption of the Constitution of RP required a reform of the administrative judiciary, the part of which inevitably had to be anchoring the stages of appeal into the administrative court proceedings. Two slightly different sets of law proposals emerged. Parliamentary bills calculate with the creation of three-tier structure of administrative judiciary. ${ }^{64}$ By contrast, presidential bills ${ }^{65}$ counted on the creation of a two-tier structure of administrative judiciary formed by voivodship administrative courts and the Supreme Administrative Court, while retaining the principle of two instances of appeal in the administrative proceedings and its introduction in administrative court proceedings. Presidential bills represented the basis for the current legislation of the organization of administrative courts, and in 2002 the act on the organisation of administrative courts was approved (hereinafter referred to as p.u.s.a.) ${ }^{66}$. Two-tier structure of administrative courts is therefore formed by voivodship administrative courts and the Supreme Administrative Court (hereinafter NSA).

In accordance with the Constitution of RP, courts are separate and on other authorities independent bodies, which decide on behalf of the Republic of Poland. Judges are appointed for an indefinite term and are independent in the performance of office, subject only to the Constitution of PR and the law. ${ }^{67}$

\subsection{Voivodship administrative courts}

Voivodship administrative courts (hereinafter WSA) act as courts of first instance and may be established for each province (voivodship) or for more voivodships. Voivodship administrative courts are created and dismissed by regulation, which following the proposal of the President of NSA is issued by the President of the Republic. Similarly, the seats of WSA and their local jurisdiction is determined. In addition to WSA, local branches may be created outside the seat of the particular WSA, also in the form of a regulation by the President of the Republic following the proposal of the President of NSA. Branches are not separate courts, but they form a part of the particular court. ${ }^{68}$ Currently, there are 16 voivodship administrative courts, ${ }^{69}$ i.e. one WSA is located on the territory of

64 Sejm of the Republic of Poland, 2001, IV. election period, prints No. 77, 78 a 79, available on www.sejm.gov.pl. Also see KIJOWSKI, Dariusz (red.) Dwuinstancyjne sądownictwo administracyjne. Raport Programu Administracji Publicznej. Warsaw: Instytut Spraw Publicznych, 2000.

65 Sejm of the Republic of Poland, 2001, IV. election period, prints No. 18, 19 and 20, available on www.sejm.gov.pl.

66 Act Coll. 2002 No. 153, item 1269.

67 See Article 173, 174, 178 (1), 179 of the Constitution of RP.

68 MASTERNAK-KUBIAK, Małgorzata In MASTERNAK-KUBIAK, Małgorzata, KUCZYŃSKI, Tadeusz. Prawo o ustoju sądów administracyjnych. Warsaw: Wolters Kluwer, 2009, p. 179.

69 See Regulation by the President of the Republic of Poland - Coll. 2003 No. 72, item 652.

\footnotetext{
(C) Palacký University Olomouc, Czech Republic, 2012. ISSN 1213-8770 (print), ISSN: 2464-6601 (online).
} 
each province. ${ }^{70}$ In addition, a local branch of voivodship administrative court in Warsaw was established in Radom. ${ }^{71}$

Voivodship administrative courts are internally subdivided into departments governed by the President or Vice-President of the court or an authorised judge. Departments are created and dissolved by the President of NSA.

Voivodship administrative courts consist of the President of the court, VicePresident or Vice-Presidents of the court and individual judges. The number of WSA judges is determined by the President of NSA.

In accordance with the constitutional arrangements, a WSA judge is appointed by the President of the Republic of Poland following a proposal by the National Council for the Judiciary without counter-signing. ${ }^{72}$ A person can be appointed as judge of voivodship administrative court if he/she is a citizen of the Republic of Poland, is not limited in their civil rights, has a spotless character, completed a law degree in Poland (a Master's degree) or comparable study abroad subsequently certified in Poland, is able to fulfill the obligations of judge with regard to their health, is at least 35 years of age, is characterised by a high level knowledge in areas of public administration and administrative law and other areas of the law relating to the activities of public authorities and worked for at least 8 years as a judge, prosecutor, President, Vice-President, senior adviser or adviser to the General Prosecutor's Office of the Treasury or practised for at least 8 years as a lawyer, legal adviser or notary, or who worked for at least 10 years in public institutions on the positions related to the application or preparation of administrative law regulations, or worked for at least 2 years as a judicial trainee at a voivodship administrative court.

Requirements for the practice need not comply with the scientific title of Professor or with the scientific degree of habilitated Doctor of Law. Such persons may also carry out their duties of judge in an incomplete extent of working time.

The President of NSA may for a certain period of time entrust a WSA judge, with their consent, with the function of the Supreme Administrative Court judge. Following a proposal by the President of the court, the Minister of Justice may entrust, with their consent, an appellation court judge or a regional court judge, i.e. of general courts, with the function of the administrative court judge (WSA or NSA).

Bodies of the WSA are represented by the President of the court, the plenary assembly of the judges of voivodship administrative court and the bench of voivodship administrative court.

70 See Article 2 of the Act Coll. 1998 No. 96, item 603.

71 See regulation by the President the Republic of Poland - Coll. 2005 No. 256, item 2144.

72 See Article 144 (3), point 17 in conjunction with Article 179 of the Constitution of PR.

(C) Palacký University Olomouc, Czech Republic, 2012. ISSN 1213-8770 (print), ISSN: 2464-6601 (online). 
President and Vice-President of WSA is appointed by the President of NSA from among the WSA or NSA judges. The term of office is five years and only two consecutive terms are permitted. The appointment of the President of WSA requires by law that the President of NSA had received the opinion of the Plenary Assembly of judges of the particular court. If the opinion is not expressed within two months, the President of the court may be appointed without an opinion. In case of a negative opinion the law provides for the option for the President of NSA to request the opinion of the National Council of the Judiciary, and the President of WSA may be appointed based on the Council's positive opinion. A negative opinion of the National Council of the Judiciary is binding for the President of NSA. However, even here the law provides for the possibility that the National Council of the Judiciary does not issue an opinion on the candidate. If it fails to do so within a 30 -day period, it is considered that the opinion is positive.

President or Vice-President of WSA may be removed by the President of NSA, if they fail seriously in duties or if further exercise of these functions would not be in accordance with the correct performance of judiciary. A positive opinion by the Plenary Assembly of judges and the National Council of the Judiciary is needed for the removal. If the authorities do not respond within one month, the opinion is considered to be positive. The President or Vice-President may of course resign. In this case, the President of NSA removes them without the opinion of these bodies.

President of the court governs the court and represents it. The President also carries out judicial administration, being a subordinate body of the President of NSA. President of WSA is substituted by the Vice-President of court or by a designated judge.

Plenary Assembly of voivodship administrative court represents an authority of judicial self-government ${ }^{73}$ and is composed of all WSA judges, chaired by the court's President. Plenary assembly discusses the annual report of the President of the Court, presents candidates for WSA judges to the National Council of the Judiciary, expresses its views on the appointment and removal of the President and the Vice-President of court, specifies the number of members of court divisions, chooses its members and makes changes in its composition, chooses from among themselves two members to attend the Plenary Assembly of NSA judges which proposes candidates for members of the National Council of the Judiciary, and discusses and expresses opinions on other matters, submitted by the President of court or members of Plenary Assembly. ${ }^{74}$

73 MASTERNAK-KUBIAK, Małgorzata In MASTERNAK-KUBIAK, Małgorzata, KUCZYŃSKI, Tadeusz, op. cit., p. 208.

74 See Article 24 p.u.s.a. 
The court divisions of voivodship administrative courts distribute activities performed by the court and describes detailed principles of the allocation of cases to individual judges, presents candidates for WSA judges to the National Council of the Judiciary, discusses issues submitted to the Plenary Assembly, examines other cases submitted by President of the court or on its own initiative. The term of office of the court division is three years. Court division is chaired by the President of the court.

In addition to judges, judicial trainees also operate in WSA, as well as senior judicial officers, senior assistant judges and assistants judges and officers and other court staff.

Judicial trainee is appointed by President of NSA from among the people who satisfy the above mentioned conditions for the appointment as a judge, with the exception of the prescribed age and practice, where the law stipulates milder conditions. The President of NSA may, subject to agreement of particular division of WSA, authorize judicial trainee to perform judicial activities in WSA, but only for a fixed period not exceeding five years. Here it should be noted that similar legal arrangements in the law on the organization of general courts ${ }^{75}$ were pronounced as unconstitutional by the Constitutional Tribunal. ${ }^{76}$

Judicial officer exercises the activity of mediation, as well as other judicial activities stipulated by law. Judicial officer who performed this function for at least 10 years without disciplinary punishment and regularly received positive qualifications evaluation, may be appointed a senior officer. The task of assistant judge is to independently carry out certain activities of judicial administration and prepare cases for discussion. Assistant judge, who performed this function for at least 10 years without disciplinary punishment and regularly received positive qualifications evaluation, may be appointed a senior assistant judge.

Internal office regulations of voivodship administrative courts are issued by the regulation of the President of the Republic. ${ }^{77}$ Internal office regulations regulate the internal organization of courts, principles of their operation, method of execution of judicial activities, method of determining the composition, in which the court shall decide, with regard to the specialization of judges and idea of matters.

\subsection{The Supreme Administrative Court}

As indicated above, the system of administrative courts in the Republic of Poland is completed by the Supreme Administrative Court based in Warsaw. The Supreme Administrative Court operated as a single-instance court after the

75 Act Coll. 2001 No. 98, item 1070.

76 See Judgments of the Constitutional Tribunal of 24 October 2007, SK 7/06, LexPolonica No. 1639572.

77 See Coll. 2003 No. 169, item 1646. 
renaissance of the Polish administrative judiciary in the years 1980 to 2003 . The last reform was therefore performed "downwards", and the existing Supreme Administrative Court became the top of the newly established system of administrative courts.

Supreme Administrative Court consists of the President of NSA, Vice-Presidents and judges. The number of NSA judges is specified by the President of the Republic in the form of a regulation issued by the plenary assembly of NSA. ${ }^{78}$

A person may be appointed a judge of the Supreme Administrative Court who fulfills the conditions for the appointment as a judge of voivodship administrative court and is at least 40 years old, or performed for at least 10 years duties of judge or public prosecutor or the President, Vice-President, senior adviser or adviser of the General public prosecutor's office of the Treasury or practised as a lawyer, legal advisor or notary for at least 10 years. The age limit 40 years of age does not apply to anyone who performed for at least 3 years the duties of judge at a voivodship administrative court. The condition of the prescribed period of practice in one of the listed legal professions need not be met by a person possessing the scientific degree of Professor or habilitated Doctor of legal sciences. In this case such persons may also perform their duties of judge in an incomplete extent of working time.

Supreme Administrative Court is divided into three chambers: the Financial Chamber, the Commercial Chamber and the General Administrative Chamber. ${ }^{79}$ Chambers supervise decision-making activities of voivodship administrative courts. Activities of each of the Chambers is governed by one Vice-President appointed by the President of NSA.

The Supreme Administrative Court also includes the Office of the President of the Supreme Administrative Court and the Judicature Department.

The Chambers of NSA, Office of the President of NSA and the Judicature Department are further subdivided into departments, that are, with agreement of the court division of NSA, established and dismissed by the President of NSA.

78 See Coll. 2004 No. 26, item 228. In accordance with this regulation 95 judges work at NSA, 4 of which are Vice-Presidents of the court.

79 See Article 39 p.u.s.a. The scope of the Financial Chamber includes issues of tax liabilities and other money contributions from the area of tax law and their execution. The scope of the Commercial Chamber includes economic activity, protection of industrial property, budget, currency, securities, banking, as well as insurance, customs, prices, tariff rates and fees. Finally, the General Administrative Chamber deals with matters not covered by other NSA chambers, in particular those concerning construction and supervision of construction projects, land development, water management, natural environment conservation, agriculture, forestry, employment, system of local government, real estates management, privatisation of property, compulsory military service, internal affairs, as well as prices, fees and tariff rates, provided that they are connected with matters falling within the scope of competence of the Chamber. 
$\mathrm{He} /$ she also appoints and removes their Presidents, the Head of the Office of the President of NSA and the President of the Judicature Department.

Bodies of the Supreme Administrative Court are represented by the President of NSA, the Plenary Assembly of NSA judges and the NSA court division.

The head of NSA is the President of NSA, who manages its activities, represents it and supervises the administrative activities of administrative courts. The President and Vice-Presidents of NSA are appointed by the President of the Republic without counter-signing. ${ }^{80}$ The President is chosen from one of two candidates proposed by the Plenary Assembly of NSA judges from among the NSA judges, for the term of 6 years. ${ }^{81}$ The President of NSA exercises judicial administration with respect to NSA, and other activities stipulated by law. An essential tool of separating administrative courts from public administration and executive power in general is the removal of powers in the judicial administration from the Minister of Justice, in relation to general courts. This principle is based on the fact that administrative courts exercise the control of public administration, and therefore of the Ministers. As a result, these powers are exercised by the President of NSA $.^{82} \mathrm{He} / \mathrm{she}$ also has the powers of the Minister of Finance with regard to administrative courts' budgets. ${ }^{83}$

President of NSA can submit a proposal to the Constitutional Court in matters of abstract control of constitutionality, as well as on the conflicts of jurisdiction between the central constitutional authorities of the state. ${ }^{84}$ Moreover, he may propose to the NSA to adopt a resolution explaining legal provisions, the application of which has generated divergence in the decision-making practice of administrative courts.$^{85}$ The President of NSA also issues official collection of decisions of administrative courts and annually reports to the President of the Republic and the National Council of the Judiciary on the activities of administrative courts. In addition, NSA also issues professional legal magazine (Zeszyty Naukowe Sądownictwa Administracyjnego).

President of NSA is substituted in range specified by him by the Vice-Presidents of NSA. In addition, he/she may entrust certain judges with certain activities in the field of judicial administration. Vice-Presidents of NSA are appointed by the President of the Republic following a proposal of the President of NSA, with the consent of the Plenary Assembly of NSA judges. Vice-President of

80 See Article 144 ( 3), points 22 and 23 of the Constitution of PR.

81 See Article 185 of the Constitution of PR in conjunction with Article 44 p.u.s.a.

82 See HAUSER, Roman. Założenia reformy sądownictwa administracyjnego. Państwo i Prawo, 1999, No. 12, p. 26-27.

83 Part of the state budget proposal with regards to administrative courts is processed by the President of NSA and the Minister of Finance only attaches it to the draft of the state budget.

84 See Article 191 (1) point 1 and Article 192 of the Constitution of PR.

85 For more see below. 
WSA may be removed by the President of the Republic, following a proposal by the President of NSA, if they fail seriously in duties or if further exercise of these functions would not be in accordance with the correct performance of judiciary. For such a proposal, however, the President must obtain the consent of NSA Plenary Assembly. Such consent is not needed, if the Vice-President resigns. In such case the President of NSA shall propose his removal.

NSA judges form the Plenary Assembly of judges of the Supreme Administrative Court, being the body of judicial self-government, ${ }^{86}$ lead by the President of the Supreme Administrative Court. The Plenary Assembly of NSA judges examines the annual report of the President of NSA on the activities of the court, presents candidates for the position of judges to the National Council of the Judiciary, selects candidates for the President of NSA, approves designation or removal of the Vice-President of court, determines the number of members of NSA division, selects its members and the changes in its composition, as well examines other issues submitted by the President of NSA or members of the Plenary Assembly of NSA judges and issues opinions on those.

Plenary Assembly of NSA judges approves the internal office regulations of the Supreme Administrative Court, which must be published in the Official Collection of the Republic of Poland.

The court division of the Supreme Administrative Court also represents a body of judicial self-government. ${ }^{87}$ The court division specifies the distribution of activities performed by the court and describes detailed principles of the allocation of issues to individual judges, presents opinions on candidates for the position of judges to the Plenary Assembly of NSA judges, authorizes the establishment and dismissal of divisions and the appointment and removal of their presidents, the President of the Office of the President of NSA or the President of the Judicature department, discusses matters submitted to the Plenary Assembly of NSA judges, as well as other issues submitted by the President of the court or from its own initiative. The term of office of NSA court division, lead again by the President of the Supreme Administrative Court, is 3 years.

Supreme Administrative Court decides in disciplinary proceedings of judges of administrative courts, both in the first (formed by three judges) and in the second (formed by seven judges) instance. ${ }^{88}$

86 MASTERNAK-KUBIAK, Małgorzata In MASTERNAK-KUBIAK, Małgorzata, KUCZYŃSKI, Tadeusz, op. cit., p. 287.

87 MASTERNAK-KUBIAK, Małgorzata In MASTERNAK-KUBIAK, Małgorzata, KUCZYŃSKI, Tadeusz, op. cit., p. 291.

88 See Article 48 p.u.s.a. 


\subsection{Supreme Administrative Court as a supervisory body}

Supreme Administrative Court supervises the decision-making activities of WSA, in particular decides about appeals against the decisions of courts and adopts resolutions addressing legal issues. ${ }^{89}$ Supreme Administrative Court, however, is not responsible for supervision of the decision-making activities of courts in the administrative judiciary at the constitutional level. On the other hand, according to certain officials of doctrine, the constitutional task of the Supreme Administrative Court is to supervise the activities of voivodship administrative courts, even though it's not explicitly stated in the Constitution of PR. ${ }^{90}$

Supreme Administrative Court decides cassation appeals and complaints as appeals against the decision of voivodship administrative courts ${ }^{91}$ or statement of invalidity of a court decision, ${ }^{92}$ which represents a means of supervision of the decision-making activities of WSA, and means of self-control of decisions issued by NSA. ${ }^{93}$

Besides decision-making on these remedies NSA also accepts resolutions addressing legal issues. ${ }^{94}$ These resolutions are of two types: 1) specific and 2) abstract. The subject of specific resolutions are legal doubts, which result from the discussion of any remedy of NSA and therefore are in close relation with the procedure in the individual case discussed by the NSA..$^{95}$ In contrast, abstract resolutions are adopted in order to address the legislation, the application of which has created differences in judicature of administrative courts (not only NSA but also WSA). In contrast to specific resolutions, they are in no immediate relation with specific proceedings at administrative courts. ${ }^{96}$ Both forms of resolutions are adopted by NSA panel of seven judges, by a Chamber or in plenary. The panel of seven judges can, in the form of a resolution, present a legal question for decision to a Chamber, and the Chamber can do the same to the NSS plenary. Specific resolutions are adopted by NSA if the procedure for dealing with the cassation appeal or appeal uncovers a legal question causing serious doubts. In this case, NSA can postpone hearing of the case and submits

89 See Article $3 \S 2$ p.u.s.a.

90 BANASZAK, Bogusław. Konstytucja Rzeczypospolitej Polskiej. Komentarz. Warsaw: C.H.Beck, 2009, p. 814.

91 See Article 173 an. and Article 194 an. Act on the proceedings before administrative courts (Coll. 2002 No. 153, item 1270; hereinafter referred to as p.p.s.a.). For literature see e.g. KANIA, Michał. Zwyczajne środki zaskarżenia w postępowaniu przed sądami administracyjnymi. Warsaw: Wolters Kluwer, 2009.

92 See Article 172 p.p.s.a.

93 See ROMAŃSKA, Marta In WOŚ, Tadeusz (red.), op. cit., p. 303. Supreme Administrative Court shall declare invalid any decision by administrative courts.

94 See Article 264 an. p.p.s.a.

95 HAUSER, Roman, KABAT, Andrzej. Uchwały Naczelnego Sądu Administracyjnego w nowych regulacjach procesowych. Państwo i Prawo, 2004, No. 2, p. 28.

96 Ibid, p. 27-28. 
this question for the decision to the panel of seven NSA judges. The resolution of NSA panel of seven judges is binding in the particular case. Supreme Administrative Court's panel of seven judges may also accept the issue for decision. ${ }^{97}$ Adoption of an abstract resolution is proposed by the President of NSA, ${ }^{98}$ Attorney General, Commissioner for Citizens' Rights or Commissioner for Children's Rights. Supreme Administrative Court may refuse to adopt a resolution, in particular, if there is no need to remove doubts. If the administrative court (WSA or NSA) discussing a certain case does not agree with the conclusions contained in the NSA resolution addressing a legal question, it shall submit the question to the competent NSA panel, which shall adopt a new resolution. In such case is not possible to refuse the adoption of the resolution. This is the only case when adoption of a resolution may be proposed by WSA. ${ }^{99}$

In this respect, signalling powers of the President of NSA, or administrative courts, should be mentioned. President of NSA is obliged to inform the President of Council of Ministers (Prime Minister) about problems in functioning of the public administration resulting from issues discussed by administrative courts. ${ }^{100}$ In addition, in cases where administrative courts conclude in proceedings that a substantial infringement happened, or that there are circumstances affecting it, the administrative court can inform relevant bodies of public administration. ${ }^{101}$

\section{Conclusions}

Now it is time to make an assessment. In my opinion, adjustment of the organization of the Polish administrative judiciary significantly reflected the fact that this form of judicial control of public administration has been renewed already in 1980, as well as more time for the adoption of the new democratic constitution in 1990s. It was also substantially influenced by the form of the renewal of administrative judiciary in Poland, which happened "downwards" by establishing a single administrative court for the whole country. ${ }^{102}$

The Polish Supreme Administrative Court, however, also operated through its local branches, which were after the last reform transformed into voivodship

97 See Article 187 p.p.s.a.

98 See Article $36 \$ 1$ p.u.s.a.

99 WOŚ, Tadeusz In WOŚ, Tadeusz (red.) Prawo o postępowaniu przed sądami administracyjnymi. Komentarz. 3. wydanie. Warsaw: LexisNexis, 2009, p. 910. The fact that WSA do not normally have this option is not accepted without reservations (see HAUSER, Roman, KABAT, Andrzej, op. cit., p. 28).

100 See Article $15 \$ 1$ p.u.s.a.

101 See Article 155 p.p.s.a.

102 For more details see KRYSKA, David. K třicátému výročí vzniku polského Nejvyššího správního soudu. In JIRÁSKOVÁ, Věra, WITKOWSKI, Zbigniew (ed.) Ústavní systém České republiky a Polské republiky po prristoupení k Evropské Unii : II. česko-polský právnický seminár. Prague: Leges, 2011, p. 225-235. 
administrative courts. ${ }^{103}$ I believe that it's a shame that Czech legislators did not decide to establish a whole network of special administrative courts with the Supreme Administrative Court on the top. It is not only that specialisation of courts for the administrative law generally appears to be appropriate and a separate system of administrative courts can provide it more easily. ${ }^{104}$ Effectiveness of this solution is indicated by the comparison with the Polish legislation.

The solution in Poland significantly elevates the role (and the responsibility and liability) of the President of NSA in the organization of administrative courts, his/her influence on functioning and direction of the system (e.g. ensuring sufficient expertise of judges and other court staff and the efficiency of courts, and fulfilling its main responsibilities). A significant feature of this system is the separation of the judicial administration of these courts from individual ministries (Justice, Finance), which increases their independence from the public administration, the control of which is performed by administrative courts. The principle of sufficient balance of state powers is ensured under the influence and cooperation of the President of the Republic, or the National Council of the Judiciary, where appropriate.

An important step forward in the Czech reform from 2002 is the obligation of NSS to issue Collection of Decisions of NSS, the absence of which was regarded as a serious issue in $1990 \mathrm{~s} .{ }^{105}$ In addition to issuing an official collection of the decisions by administrative courts, however, the Polish NSA also issues a comprehensive public annual report on its activities, a scientific magazine and numerous scientific publications. A problem still existing in the Czech Republic is, in my opinion, the insufficient "permeability" of staffing at administrative courts for the representatives of scientific community and administrative authorities. ${ }^{106}$ Administrative court judges virtually do not differ from the judges of general courts and higher requirements imposed on them are considered to be an exception from general rules. to them are considered to be rather as a derogation from the general rules. Also here the Polish legislation can be very inspiring.

Finally, let me express my agreement with $R$. Hauser and A. Kabat with regards to legislation amendment which would allow voivodship administrative courts to issue resolutions addressing legal issues also during the proceedings

103 See HAUSER, Roman. U progu reformy sądownictwa administracyjnego. Państwo $i$ Prawo, 2002, No. 11, p. 40 .

104 For more on the issue see LEGOMSKY, Stephen. H. Specialized justice: courts, administrative tribunals and a cross-national theory of specialization. New York : Oxford University Press, 1990.

105 See e.g. MIKULE, Vladimír. Význam správního soudnictví pro všeobecnou právní kultivaci veřejné správy. Správní právo, 1997, No. 3-4, p. 141-142; MAZANEC, Michal. Problémy českého správního soudnictví pohledem soudce. Správní právo, 1997, No. 3-4, p. 149-150.

106 See MAZENEC, Michal. K úvahám nad záměry reformy správního soudnictví. Časopis pro právní vědu a praxi. 2002, No. 2, p. 233. 
held there. Similarly, procedure for forming opinions by the Czech NSS should be also adapted. Such adjustment of "preliminary question" would in my opinion allow for better unification of judicature and it would also contribute to cultivation of public administration. In this context, perhaps even more than in Poland, the institute of cassation appeals is preferred here. However, not every decision of the court of "the first instance" must (or can, due to inadmissibility) be contested at the Supreme Administrative Court.

Not only for these reasons I believe that is legitimate not to settle completely for the Czech reform of 2002, but to continue to discuss and analyze the options for establishing a whole system of administrative courts. ${ }^{107}$

107 I'm leaving aside the option of establishing independent administrative tribunals and I refer in this matter to KRYSKA, David. Idea nezávislých správních tribunálů a její možné uplatnění $\mathrm{v}$ cizineckém a azylovém právu se zaměřením na českou a polskou právní úpravu. In JÍLEK, Dalibor, POŘÍZEK, Pavel (eds.) Návratová směrnice: vyhoštění, zajištění a soudní přezkum. Sborník z vědeckého semináře uskutečněného dne 20. ř́ijna 2011 v Kancelári veřejného ochránce práv. Brno: Kancelář veřejného ochránce práv, 2012 (in print). 